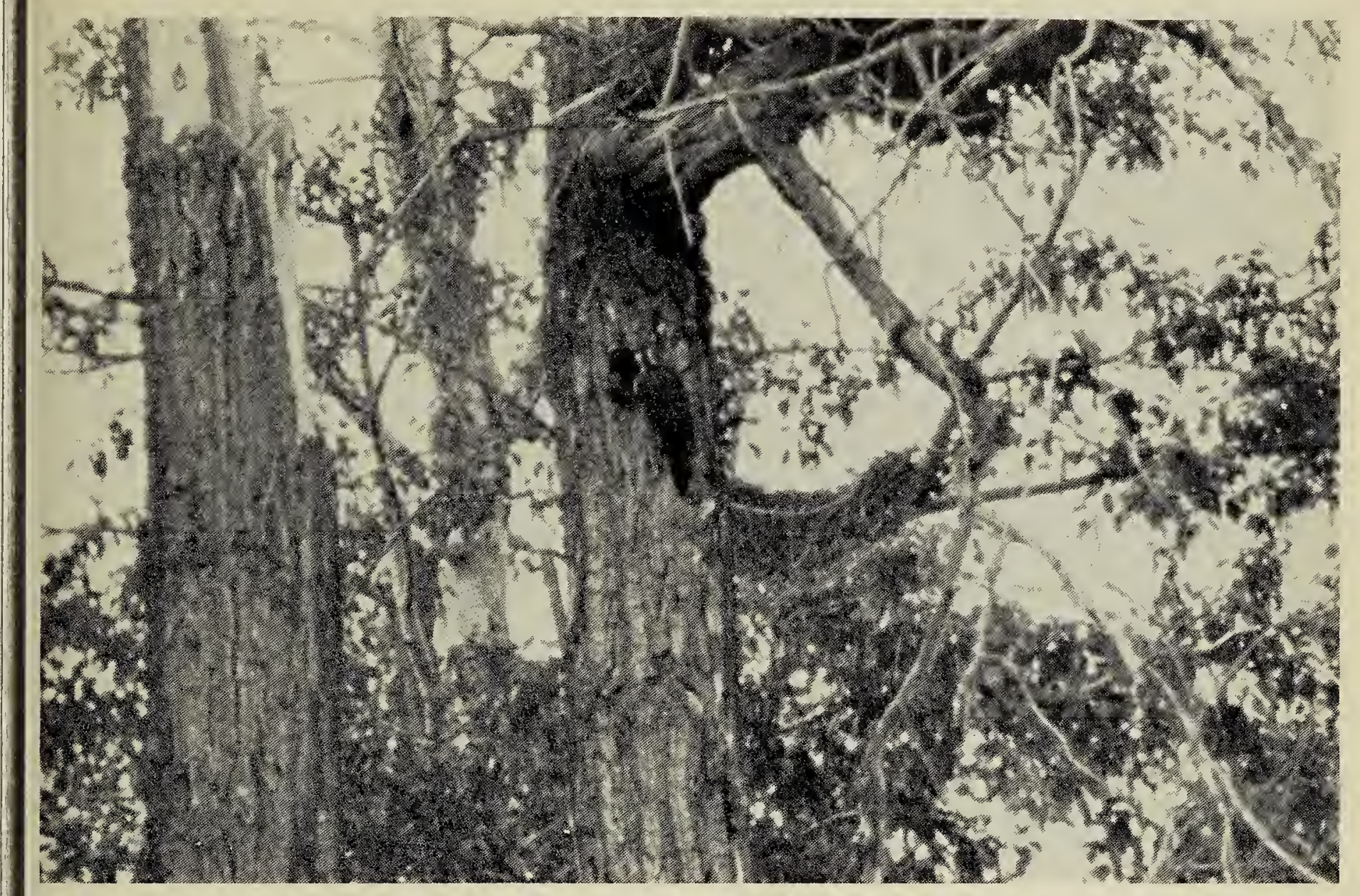

Pileated Woodpecker at nesthole

Hans DeVogel

\section{PILEATED WOODPECKERS NESTING ON THE NORTH SASKATCHEWAN RIVER}

HANS DEVOGEL, Box 219 , Neilburg,
Saskatchewan, SOM $2 \mathrm{CO}$.

Going upstream on 22 May 1979 from my camping place on the Big Gully Creek, Saskatchewan, to inspect the heron rookery on Cranberry Island, I found the nest of a pair of Pileated Woodpeckers. The herons had deserted the rookery and relocated a mile farther upstream.

On one of the dead black poplars was a Pileated Woodpecker drumming and calling; another bird disappeared in a hole right under an old heron's nest. After about 10 minutes, it popped out again, and both birds flew across the river.

On 3 June I went back and climbed the steep river bank and set up a tri- pod for my Pentax and $200 \mathrm{~mm}$ lens. After waiting about an hour, one bird came from across the river, perched in a nearby tree and gave a soft call. The other bird flew out of the nesting hole right away. After a short while, the new arrival went in. It was apparent that both parents shared incubation.

I later observed that the young were fed roughly every two hours by both parents. At first an adult would go into the nest to feed the young, come out again and perch in a nearby tree. After a while it went back in and when it came out it flew to the same tree. I suppose this was to clean out the nest.

As the young got bigger, they would stick their heads out of the nesting hole and were fed from outside. The nest was not cleaned out then, because there was no room for the old bird to get in. 
The actual feeding period was very short. I never saw the parents carry anything in their beaks. Coming in with food, they never flew directly to the nest hole, but perched in a nearby tree and looked around for awhile. On one occasion, a bird landed above the nest and had to back down.

The young Pileated Woodpeckers did not make the same burring noise that young flickers do. Instead they made a sort of ted, ted, ted which later turned into the adult call. The parents were very silent at first when the young were about ready to leave the nest, then there was a lot of calling going on, answered in the same way by the young. To my surprise, the young had the same red crest as the

\section{POSSIBLE SWALLOW} RESPONSE TO INSECTICIDE USE

G.A. WILDE, Box 1196, Hinton, Alberta, TOE $1 B 0$.

Each year for the past five years, an average of two clutches of Tree Swallows and three clutches of Cliff Swallows has been successfully reared in my yard in Hinton, Alberta. This year on 9 June 1979, I used an insecticide (Cygon 2E) to combat an outbreak of Birch Leaf Miner. The insecticide was liberally applied to the trunks of six Balsam Poplars, two White Birch and five Manchurian Elms. This was the first application of an insecticide since 1972. At approximately the same date, several neighbours also applied a variety of insecticides to combat the same outbreak.

The next day, I noticed the absence of both species of swallows and for 14 days following the application of the insecticide, I did not see any swallows in my yard; however, in an adjacent parents.

I was fortunate enough to be present on 8 July when the first young left the nest. It just popped out of the nesting hole and landed none too gracefully between the two parents on a nearby tree. Then I found out that there were more than two young in the nest because again, two little red heads pushed out of the nest hole.

For about four hours, I never saw the old birds feed the two young left in the nest; it was a matter of "if you want it, come and get it". As far as I could see, the young had the same plumage as the old ones, but were a little smaller.

Unfavorable weather prevented me from making further observations.

yard where insecticides were not applied, swallows continued with their nesting activities. On 16 June 1979, I examined my nesting boxes (one on the garage and the other on a 3-metre post) and found a very disturbed nest containing six eggs and an intact nest with one egg. I also examined the six Cliff Swallow nests on my house. They contained: two dead young, one egg, 3 empty swallow nests and one House Sparrow nest. The first swallow activity I noticed in my yard after the insecticide application was on 23 June when a number of Cliff Swallows briefly visited the nest which had contained young.

During this period of time (9-23 June) House Sparrows, Starlings, Robins, and Pine Siskins were frequent visitors to my yard and a Chipping Sparrow nested in a conifer with no noticeable response to the insecticide application on the adjacent trees.

I believe the desertion of the nests and the avoidance of the yard by swallows was directly related to the application of the insecticide. 